\title{
The Impact of Percieved Usefulness, Ease of Use and Trust on Managers' Acceptance of e-Commerce Services in Small and Medium-Sized Enterprises (SMEs) in Palestine
}

\author{
Fadi Herzallah $^{\# 1}$, Muriati Mukhtar ${ }^{\# 2}$ \\ ${ }^{\#}$ Research Center for Software Technology and Management, Faculty of Information Science and Technology, \\ Universiti Kebangsaan Malaysia, 43600, Bangi, Selangor, Malaysia. \\ E-mail: ${ }^{1}$ fadi.herzallah@yahoo.com, ${ }^{2}$ muriati@ukm.edu.my
}

\begin{abstract}
Internet revolution, specifically using the internet in a business environment has resulted in significant changes in how business conducted in small and medium-sized enterprises (SMEs). Recent research has pointed to the important role that electronic commerce (EC) plays in improving the performance of SMEs. Yet, in the context of Palestine, adoption of EC in SMEs is still slow. Therefore, the current study aimed to investigate the effect of perceived ease of use, perceived usefulness and perceived trust on managers' acceptance of EC in SMEs. In order to achieve this, the study used the technology acceptance model (TAM). The study used a survey that administered to 250 managers of SMEs from Palestine. The data was analysed employing a structural equation modelling (SEM) approach through partial least square (PLS) software. The results revealed that perceived trust and perceived usefulness had positive effects on the participating managers' behavioural intention to adopt EC services. It also found that the manager's perception, including their perceived ease of use, significantly affected their perceived trust of using EC services. Moreover, perceived ease of use had a significant impact on perceived usefulness. However, the managers' perceived ease of use failed to predict their intention to adopt such EC services, and perceived usefulness failed to predict their perceived trust. Based on these results, the study offers a developed research model of the major factors that affect managers' trust to accept and use EC services in SMEs.
\end{abstract}

Keywords - e-Commerce; perceived ease of use; perceived usefulness; trust

\section{INTRODUCTION}

The increasing and speedy technological innovations have paved the way for new frontiers and possibilities for both organizations and customers [1]. For decades, researchers have been interested in exploring the idea of performing online or electronic business transactions as an alternative to the traditional or face-to-face (FTF) mode of transactions [2]. Regarding this, one of the interesting recently emerging topics of business research is Electronic Commerce (EC). As an important research area, since the initial use of the Internet for commercial purposes dated back to 1990s, EC has attracted the attention of many researchers.

The increasing attention of researchers to EC supports the role of such speedy technological innovations in penetrating many sectors, including Small and Medium-Sized Enterprises (SMEs). Therefore, SMEs have adopted technologies as a means to promote their internal and external activities and services. Within the need calling for the importance of technological adoption in different workplace contexts and its benefits, SMEs motivated by the various benefits advocated by technology, particularly the application of EC in various organizations or companies. These benefits are attracting new customers, reducing the costs of conducting business, penetrating suppliers, enhancing or improving the products and services as well as generating new ways or channels for product distribution [2], [3]. These benefits can even be realized by both SMEs and large firms [4]. Being motivated by this role of technologies in SMEs, which are an important driver of the economic growth of any country, researchers and practitioners carried out many empirical studies focusing on the acceptance and utilization of EC in SMEs [5]-[7].

Although results of most above cited studies support the role of EC in offering different potential advantages, its adoption among SMEs in the Palestinian context is still limited [8]. Although EC adoption is advantageous in SMEs, there are still several challenging issues, including trust that burdens the acceptance and adoption of EC among managers of SMEs. Concerning this, previous researchers exploring the role of EC in SMEs emphasized the need for investigating managers' trust in order to provide better understanding of how this affects their acceptance and use of such EC services [9]-[11]. Therefore, the aim of the current study was to examine the impact of perceived ease of use 
(PEOU), perceived usefulness (PU) and perceived trust (PT) on the acceptance and use of EC services among managers of SMEs in the context of Palestine.

There are different definitions of the concept of EC offered in previous related research [12]. Thus, some general definitions of EC denote that EC refers any business-related activities, which transacted electronically or online. For instance, as defined by Swatman [13], EC is a concept used to refer to any business activity or even process which is enabled electronically. Although this definition is clear, it sounds simplistic for it does underlie any other addressed issues related to the subject. There are other definitions of $\mathrm{EC}$, which restrict EC activities to the Internet. One of these definitions is the one provided by Schneider [14] in which EC covers all businesses activities which are sold and bought using technologies such as the Internet. Yet, this definition did not account the emergence of EC, which was in the 1970s, prior to the launch of the Internet. As opposed to the cited definitions, there are other definitions of EC, which included the applicability of EC through networks, including the Internet. One example of these definitions is the definition offered by Turban, et al. [15] indicates that EC refers to any process in which products or information or even services bought, sold, transferred and exchanged by people via computer networks, including the Internet. In the present study, we used this operational definition of the concept of EC: EC refers to any activities oriented towards economy and business, which carried out to facilitate, enable and transact the processes of buying and selling of products and services between and among businesses, individuals, governments or other organizations. Such activities are carried out via Information Communication Technology (ICT) [16].

EC is described as an umbrella concept that encompasses various types of existing and new applications [17]. In brief, EC includes the followings five major types:

- Business-to-Consumer EC (B2C): In this type of EC, business conducted online with the aim of reaching or targeting individual consumers.

- Business-to-Business EC (B2B): The aim of this type of $\mathrm{EC}$ is to sell or conduct business with other businesses, and Business-to-Government (B2G) classified as a subset of B2B.

- Consumer-to-Consumer EC (C2C): This type of EC functions as a means of selling, buying and exchanging products and services among consumers with the help of an online market maker such as the auction site.

- Peer-to-Peer EC (P2P): This type of EC enables direct exchange and sharing of files and computer resources through the Internet without going through a central web server.

- Mobile EC (m-commerce): This type of EC enables complete transactions of products and services using mobile phones through text messages or data via a public or private network.

Thus, the first three types of EC listed are based on the market relationship between two parties: a seller and a customer or buyer [18]. However, the other two types of EC: $\mathrm{P} 2 \mathrm{P}$ and $\mathrm{M}$-commerce are technology-based distinctions. In other words, they distinguished by the technology being used.

\section{MATERIALS AND METHODS}

One of the most well-known theories used in previous research investigating the integration of technologies in various domains, including EC is the technology acceptance model (TAM) which was initially proposed and developed by Davis [19] based on the theory of reasoned action (TRA) [20]. As postulated by the TRA, whenever any particular behaviour exhibited by an individual, it is necessary to elicit his/her salient beliefs about the attitude towards that specific behaviour (e.g., buying on the web). This is in order to make it associated or related to that specific behaviour be investigated. The present study used the TAM by Davis [19] as the research model. The reason behind this is the effectiveness or usefulness of the TAM in predicting people's adoption and use of new technologies [19], [21] in general and EC in particular [22], [23]. Moreover, the application of the TAM in research into technology use in different fields has made such research more efficient. The model also assists researchers to aggregate results across settings [24].

As a simplification to TRA, the TAM provides an explanation of users or adopters decisions to accept new technologies. Such decisions made depending on their rational assessment of its expected outcomes, reflected by two main constructs: (1) perceived ease of use (PEOU) and (2) perceived usefulness (PU). PEOU, as proposed by Davis [19], refers the extent to which the user or adopter of technology expects that the use of specific technology would be easy or "free of effort" [12]. It regarded as the basic construct or factor used in prediction of user's behavioural intention in adopting new technologies. Thus, there are certain parameters used for measuring the construct of PEOU of EC services: being time saving, flexibility, and easiness to interact with EC services [25]. As pointed by Montazemi and Qahri-Saremi [26], a novel technology which is seen by its users as an easy and useful tool to adopt will be highly used by them. Previous research indicated that PEOU is still a dominant factor in the investigation of adoption and acceptance of EC services [27], [28].

PU refers to the expectation of the user that adopting a new information technology would result in enhancing the way his/her job is performed [19]. PU, which is the second construct in the original TAM, provides an explanation and prediction of the individual's behavioural intention to use new technologies [19]. In the context of the present study, PU among managers of EC services assumed to arise because of the perceived benefits of adopting technologies, including the reduction of expenses, easy access, easy usage, reliability, and abundance of information, low cost and saving time. These advantageous characteristics are crucial for those managers in order to accept adoption of new technologies in EC services [29], [30].

For the current study, the researcher proposed the research model in Fig. 1. In this model, the perceived trust (PT) is an additional construct in the TAM. Regarding this, PT in the online environment is defined as how the user subjectively assesses or evaluates the performance of a particular transaction by the other side (e.g., seller) will be 
accomplished as expected [31]. PT considered as a key element in the success of any commercial relationship. Thus, it contributes to the reduction of uncertainty [32]-[35]. However, the lack of PT is regarded as one of the challenging barriers in the acceptance of online transactions among users [35], [34]. The importance of PT emphasized in previous related research on EC [11], [36] is attributed to the lack of FTF or conventional financial operations in the virtual interaction between business partners and EC services.

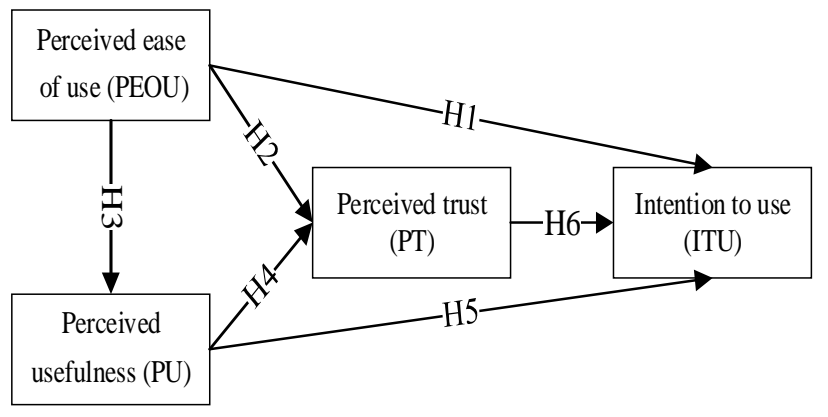

Fig. 1 The research proposed model

Concerning the relationships of effect among the above three constructs: PEOU, PU, PT and intention to adopt/use technologies, previous research reported that PU directly affects users' intentions to adopt a new technology [37]. However, there is no consensus about the impact of PEOU on technology users' behavioural intention to use such technology. In the original TAM, as argued by Davis [19], PEOU has an impact on the users' intended use, which is realized through PU. This means that such effect of PEOU on the behavioural intention is indirect. However, other researchers reported that sometimes, PEOU is directly affected IT adoption. This is true especially when the task is intrinsic to the IT [38]. Moreover, due to the strong effect of PEOU on PU, PEOU is hypothesized as a strong predictor of PU [21]. The extended TAM in other subsequent studies also explained the relationship between PEOU and PT [27], [28]. It was found that PEOU significantly affects PT among users to adopt EC services [28]. PT considered as a factor that significantly predicts user's intention to accept and use EC services. As reported by previous research, PT was identified as one of the main factors having the most influence on users acceptance and use of EC [39]. Therefore, based on these arguments of the above-stated relationships of effect among the investigated constructs, the following research hypotheses tested in this study:

- H1: Perceived ease of use positively relates to manager's intention to accept and use EC services.

- H2: Perceived ease of use positively relates to perceived trust.

- H3: Perceived ease of use positively relates to perceived usefulness.

- H4: Perceived usefulness positively relates to perceived trust.

- H5: Perceived usefulness positively relates to manager's intention to accept and use EC services.

- H6: Perceived trust positively relates to manager's intention to accept and use EC services.
Quantitative research approaches used in this study. The participants were Palestinian managers of SMEs under information and communication sector (ICT). The managers $(\mathrm{N}=250)$ were selected as the samples of the study using random sampling. Concerning the number of the samples, Structural Equation Modelling (SEM) analysis, need the number of samples at least 100 [23]. Moreover, using smart PLS path modelling suggests that the size of the sample should be minimum 30 to 100 cases [23]. Therefore, 250 respondents are sufficient.

The survey used for collecting the data from the samples was adopted from previous studies on EC acceptance and use [22], [25], [40], [41], [42] as shown in the Table 1. It comprises an overall number of items (22) modified by the researcher according to the purpose of the present study. They also translated into Arabic language so that nonEnglish speaking respondents could understand and respond to them easily. In responding to each item, the respondent needs to select one of the five-point Likert-scale ranging from (1) strongly disagree to (5) strongly agree. The survey distributed to 450 managers in ICT SMEs in West Bank Palestine online and manually. However, we used only a number of 250 completed questionnaires for analysing the data in this study. The data was analysed using the SEM approach through smart PLS 2 software.

\section{RESUlTS AND DISCUSSION}

The data analysis was conducted with the help of SPSS version 22 and Smart PLS version 2. Specifically, the sample's descriptive statistics were obtained through the former software. On the other hand, the latter was employed to investigate the latent variable within the causal structure. In the next sub-sections, the statistical analysis results are presented.

\section{A. Descriptive Statistics}

Table 2 contains the characteristics of the respondents, while Table 3 tabulates the descriptive statistics of the constructs. It can be noted that in Table 3, the entire constructs' means ranged from 3.12 to 3.68. Meanwhile, the values of standard deviations ranged from 0.765 to 0.950 , indicating that the values are spread narrowly around the mean. Moving on to the values of skewness and kurtosis, the former values fall in the range -0.300 to 0.437 , while the values of the latter fall in the range 0.426 to 1.077 . Byrne [43] established the following rule of thumb for skewness and kurtosis; \pm 3 and \pm 7 respectively for normal distribution of data. On the basis of the above recommendation, the study data was deemed to be normal and suitable to be exposed to further analysis.

The measurement instrument was assessed through Cronbach's Alpha for its internal consistency. All constructs obtained Cronbach's Alpha values exceeding 0.70 and this showed high internal consistency [44]. The values confirm that the correlation among the group of items responses that measure the study constructs was deemed as good [45]. 
TABLE I

VARIABLES AND THEIR INDICATORS

\begin{tabular}{|c|c|c|}
\hline Variable & Indicator & Label \\
\hline \multirow{6}{*}{$\begin{array}{l}\text { Perceived } \\
\text { Usefulness } \\
\quad(\mathrm{PU})\end{array}$} & $\begin{array}{l}\text { EC technology enables my company to } \\
\text { accomplish specific task more quickly. }\end{array}$ & PU1 \\
\hline & $\begin{array}{l}\text { EC technology improves my job } \\
\text { performance. }\end{array}$ & PU2 \\
\hline & $\begin{array}{l}\text { EC technology in my job increases my } \\
\text { productivity. }\end{array}$ & PU3 \\
\hline & $\begin{array}{l}\text { EC technology enhances my } \\
\text { effectiveness on the job. }\end{array}$ & PU4 \\
\hline & $\begin{array}{l}\text { EC technology makes it easier to do my } \\
\text { job. }\end{array}$ & PU5 \\
\hline & $\begin{array}{l}\text { I would find EC technology useful in } \\
\text { my job. }\end{array}$ & PU6 \\
\hline \multirow{5}{*}{$\begin{array}{l}\text { Perceived } \\
\text { ease of use } \\
\text { (PEOU) }\end{array}$} & $\begin{array}{l}\text { The skills required to learn to operate } \\
\text { EC technology would be easy. }\end{array}$ & $\begin{array}{l}\text { PEOU } \\
1\end{array}$ \\
\hline & $\begin{array}{l}\text { Interacting with EC technology would } \\
\text { be flexible. }\end{array}$ & $\begin{array}{l}\text { PEOU } \\
2\end{array}$ \\
\hline & $\begin{array}{l}\text { My interaction with EC technology } \\
\text { would be clear. }\end{array}$ & $\begin{array}{l}\text { PEOU } \\
3\end{array}$ \\
\hline & $\begin{array}{l}\text { Integrating these technologies into our } \\
\text { current work practices would be easy. }\end{array}$ & $\begin{array}{l}\text { PEOU } \\
4\end{array}$ \\
\hline & $\begin{array}{l}\text { It would be easy for me to become } \\
\text { skillful at using EC technology. }\end{array}$ & $\begin{array}{l}\text { PEOU } \\
5\end{array}$ \\
\hline \multirow{5}{*}{$\begin{array}{l}\text { Perceived } \\
\text { trust } \\
\text { (PT) }\end{array}$} & $\begin{array}{l}\text { I believe that EC technology will } \\
\text { function as I expected. }\end{array}$ & PT1 \\
\hline & $\begin{array}{l}\text { I have a high degree of confidence that } \\
\text { EC technology will be working when I } \\
\text { need it. }\end{array}$ & PT2 \\
\hline & $\begin{array}{l}\text { I trust EC technology when my access } \\
\text { to the internet is stable. }\end{array}$ & PT3 \\
\hline & $\begin{array}{l}\text { I think that the technology that supports } \\
\text { the EC technology is secure all the } \\
\text { time. }\end{array}$ & PT4 \\
\hline & $\begin{array}{l}\text { In my opinion, the EC technology is } \\
\text { trustworthy. }\end{array}$ & PT5 \\
\hline \multirow{6}{*}{$\begin{array}{c}\text { EC } \\
\text { Intention } \\
\text { to use } \\
\text { (ITU) }\end{array}$} & $\begin{array}{l}\text { Our organization seeks to use new } \\
\text { technological innovations like EC in } \\
\text { the near future. }\end{array}$ & ITU1 \\
\hline & $\begin{array}{l}\text { Our Organization opines that using EC } \\
\text { technology will be a necessity in the } \\
\text { near future. }\end{array}$ & ITU2 \\
\hline & $\begin{array}{l}\text { Our organization will consider the use } \\
\text { of EC technology in the near future. }\end{array}$ & ITU3 \\
\hline & $\begin{array}{l}\text { Our organization will have specific } \\
\text { plans to use the EC technology in the } \\
\text { near future. }\end{array}$ & ITU4 \\
\hline & $\begin{array}{l}\text { Our organization will definitely use the } \\
\text { EC technology in the near future. }\end{array}$ & ITU5 \\
\hline & $\begin{array}{l}\text { Our organization will recommend } \\
\text { others to use EC technology. }\end{array}$ & ITU6 \\
\hline
\end{tabular}

TABLE II

SAMPLE CHARACTERISTICS

\begin{tabular}{|c|c|c|c|}
\hline $\begin{array}{c}\text { Sample } \\
\text { characteristics }\end{array}$ & Frequency & $\begin{array}{c}\text { Percent } \\
(\%)\end{array}$ \\
\hline \multirow{2}{*}{ Gender } & Male & 165 & 66 \\
\cline { 2 - 4 } & Female & 85 & 34 \\
\hline Number of & $4-19$ & 60 & 24 \\
\hline
\end{tabular}

\begin{tabular}{|c|c|c|c|}
\hline employees & & & \\
\hline & $20-49$ & 190 & 76 \\
\hline \multirow{3}{*}{ Age } & Under 30 years & 123 & 49.2 \\
\hline & Under 30 years & 98 & 39.2 \\
\hline & $\begin{array}{c}\text { Between } 30-40 \\
\text { years }\end{array}$ & 29 & 11.6 \\
\hline \multirow{4}{*}{$\begin{array}{l}\text { Level of } \\
\text { education }\end{array}$} & Diploma & 20 & 8 \\
\hline & Bachelor & 176 & 70.4 \\
\hline & Master & 53 & 21.2 \\
\hline & $\mathrm{PhD}$ & 1 & 0.4 \\
\hline \multirow{3}{*}{ Experience } & Less than 3 years & 69 & 27.6 \\
\hline & $3-6$ years & 92 & 36.8 \\
\hline & Over than 6 years & 89 & 35.6 \\
\hline \multirow{3}{*}{$\begin{array}{c}\text { Years of } \\
\text { internet } \\
\text { experience }\end{array}$} & Less than 5 years & 39 & 15.6 \\
\hline & $5-10$ years & 97 & 38.8 \\
\hline & Over than 10 years & 114 & 45.6 \\
\hline
\end{tabular}

TABLE III

DESCRIPTIVE STATISTICS FOR CONSTRUCTS

\begin{tabular}{|c|c|c|c|c|}
\hline Construct & PU & PEOU & PT & ITU \\
\hline Item & 6 & 5 & 5 & 6 \\
\hline Mean & 3.18 & 3.12 & 3.34 & 3.68 \\
\hline SD & 0.903 & 0.765 & 0.950 & 0.889 \\
\hline Skewness & -0.300 & -0.485 & -0.437 & -0.763 \\
\hline Kurtosis & -1.077 & -0.715 & -.983 & -0.426 \\
\hline Cronbach's alpha & 0.892 & 0.910 & 0.930 & 0.931 \\
\hline
\end{tabular}

\section{B. Measurement Model}

As pointed out by Hair Jr, et al. [46], verifying the survey for the measurement model was part of the PLS procedure. This performed based on reflective and formative constructs. Reliability and validity regarded as two major criteria, which used for testing the goodness of measures. Reliability refers to the task of testing the consistency of a certain proposed instrument in measuring a particular aspect for which it designed. Validity refers to testing how well a particular instrument measures the particular concept for which it was intended to measure [47]. Assessment of the measurement model in this study performed by following a three-element procedure: Indicator items reliability, convergent validity, and discriminant validity. Hair Jr, et al. [46] suggested that the level of item loading must be more than 0.80 , while the minimum acceptable level for the present study is 0.60 .

As illustrated in Fig. 2, the measurement model tested by employing 22 reflective indicators. It was found that one item (PU1) had a factor loading of 0.547. As suggested by Hair, et al. [48] and Henseler, et al. [49], for the items with 
factor loading values ranging from 0.40 to 0.70 , the indicator should be deleted in condition that its removal will result in increasing the composite reliability (CR) higher than the suggested threshold value. Therefore, in this study, this indicator was removed by carrying out the PLS algorithm test.

As shown in Table 4, the convergent validity of each construct tested based on the Average Variance Extracted (AVE). Convergent validity is known as is the degree to which a measure has a positive correlation with alternative measures of the same construct [46]. In this study, 0.5 was adopted as the acceptable minimum value of AVE as recommended by previous studies [46]. The results indicate that whereas PU achieved the highest value for AVE (0.789), PEOU achieved the lowest acceptable value (0.738). In brief, all these values were at the acceptable levels in relation to their convergent validity.

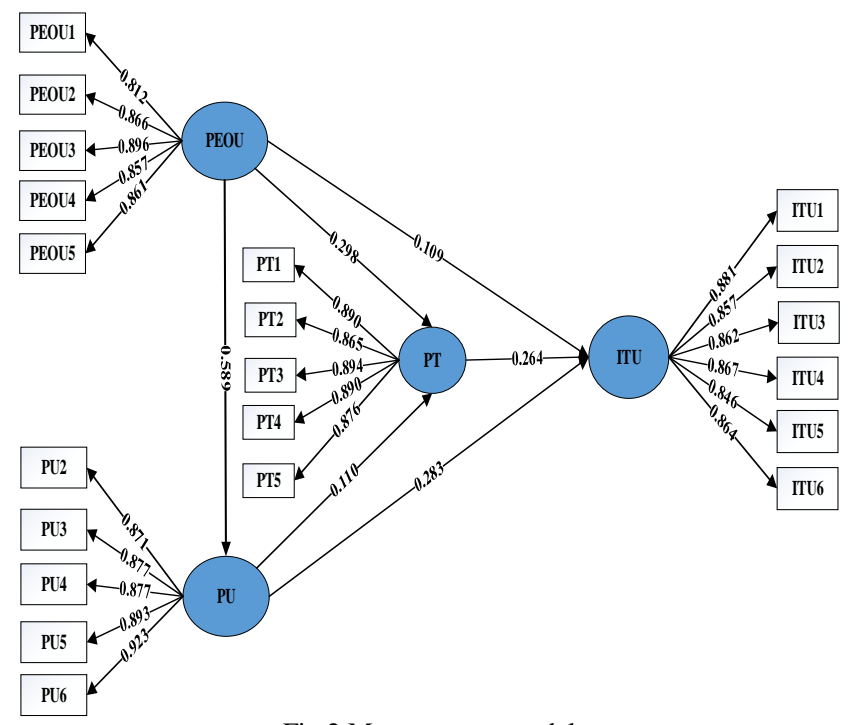

Fig.2 Measurement model

The present study applied the Fornell-Larcker criterion for assessing the discriminant validity of the examined constructs. A particular construct with the average square root of extracted variance that is higher than the correlation values of all variables are said to have such a discriminant validity [46]. As illustrated in Table 5, based on the FornellLarker criterion, the results are indicative of the adequate discriminant validity of each construct because the squared correlation for each construct is lower than the average variance extracted. The overall results also indicate that the convergent validity and discriminant validity of the model are adequate.

Based on their parameter estimates and statistical significance, the results for all the four constructs (PU, PEOU, PT, and ITU) considered valid measures of their respective constructs. The overall results suggest that the measurement model of this study showed a satisfactory empirical support for its reliability, convergent validity, and discriminant validity.

\section{Evaluation of the Structural Model}

The structural model of this study, also known as the inner model, represents the relationships of effect among the investigated constructs. Thus, evaluating the structural model means that the research hypotheses underlying the hypothesized relationships or effects among these constructs. Regarding this, the present study used path coefficient (B) criterions for testing the six research hypotheses. The path Coefficient has standardized values between -1 and +1 . The path coefficients value which is close to +1 implies that the relationship between each two constructs is strongly positive and vice versa for negative values [46]. In using this path coefficient value for assessing the significant level of the relationships, the $\mathrm{t}$-value is higher than a specific critical value suggests that the coefficient is significant at a certain error probability. For example, t-value $>1.96$ represents a significance level with a $\mathrm{p}$ - value $<0.05$.

The results obtained from testing the research hypotheses in Table 6 show that all the proposed research hypotheses accepted except for these two research hypotheses (H1 and H4). Specifically, for $\mathrm{H} 2$ assuming that PEOU had a positive influence on PT, it was found this hypothesis was accepted $(B=0.298, t=4.293, p<0.01)$. Concerning H3, the result supports the significant effect of PEOU on PU $(\beta=0.589$, $t$ $=14.688, \mathrm{p}<0.01)$. Moreover, H6 was supported by the result since PT was found to have a significant impact on the intention to use EC services $(\beta=0.264, t=4.114, p<0.01)$. This effect was even higher than the effect of PU on the intention to use EC services as hypothesized in H5 ( $B=$ $0.283, \mathrm{t}=4.155, \mathrm{p}<0.01)$. However, the results do not support $\mathrm{H} 1$ because PEOU turned out to have no positive and significant effect on the intention to use EC services ( $B=$ $0.109, \mathrm{t}=1.575, \mathrm{p}>0.01)$. Similarly, the results do not support H4 $(B=0.110, t=1.438, \mathrm{p}>0.01)$.

This study in testing the research hypotheses also used the coefficient of determination or $\mathrm{R} 2$ value. According to previous research [50], the $\mathrm{R} 2$ values ranging from 0.01 to 0.09 are considered small or low, while those ranging from 0.09 to 0.25 are regarded moderate, and those ranging from 0.25 to 1 are viewed high. In this study, the results of the calculated R2 values in Fig. 2 illustrate that the path coefficient (R2) value of PT was 0.139 . This indicates that $13.9 \%$ of the variances in PT explained by PEOU and PU. By looking closely at the results in Table 6 and Fig. 3, there is a positive correlation $(\beta=0.298, \mathrm{t}=4.293, \mathrm{p}<0.01)$ between PEOU and PT, while PU was not positively correlated with PT $(\beta=0.110, \mathrm{t}=1.438, \mathrm{p}>0.01)$. Furthermore, the R2 value of PU was found to be 0.347 , thus implying that $34.7 \%$ of the variance in PU can be explained by PEOU. The results also support the positive correlation between PEOU and PU $(\beta=0.589, \mathrm{t}=14.688, \mathrm{p}<0.01)$. This is evident that while $\mathrm{H} 2$ and $\mathrm{H} 3$ supported, $\mathrm{H} 1$ not supported. As shown from the results, the R2 value of ITUEC services was 0.262 . Thus, suggesting that $26.2 \%$ of the variances in ITU explained by PEOU, PU, and PT. There is also a positive correlation between PU and ITU $(B=0.283, \mathrm{t}$ $=4.155, \mathrm{p}<0.01)$. However, PU was not positively correlated with PT $(B=0.110, t=1.438, p>0.01)$. Finally, PT significantly predicts ITU. Hence, H5 and H6 of this study supported, but H4 was not. 
TABLE IV

RESUlts OF MEASUREMENT MODEL

\begin{tabular}{|c|c|c|c|c|}
\hline Construct & Items & $\begin{array}{l}\text { Factor } \\
\text { loading }\end{array}$ & CR & AVE \\
\hline \multirow{6}{*}{$\begin{array}{c}\text { Perceived } \\
\text { Usefulness } \\
\text { (PU) }\end{array}$} & PU1 & deleted & \multirow{6}{*}{0.949} & \multirow{6}{*}{0.789} \\
\hline & PU2 & 0.871 & & \\
\hline & PU3 & 0.877 & & \\
\hline & PU4 & 0.877 & & \\
\hline & PU5 & 0.893 & & \\
\hline & PU6 & 0.923 & & \\
\hline \multirow{5}{*}{$\begin{array}{c}\text { Perceived } \\
\text { Ease of Use } \\
\text { (PEOU) }\end{array}$} & PEOU1 & 0.812 & \multirow{5}{*}{0.934} & \multirow{5}{*}{0.738} \\
\hline & PEOU2 & 0.866 & & \\
\hline & PEOU3 & 0.896 & & \\
\hline & PEOU4 & 0.857 & & \\
\hline & PEOU5 & 0.861 & & \\
\hline \multirow{5}{*}{$\begin{array}{l}\text { Perceived } \\
\text { Trust (PT) }\end{array}$} & PT1 & 0.890 & \multirow{5}{*}{0.947} & \multirow{5}{*}{0.780} \\
\hline & PT2 & 0.865 & & \\
\hline & PT3 & 0.894 & & \\
\hline & PT4 & 0.890 & & \\
\hline & PT5 & 0.876 & & \\
\hline \multirow{6}{*}{$\begin{array}{c}\text { EC } \\
\text { intention to } \\
\text { use (ITU) }\end{array}$} & ITU1 & 0.881 & \multirow{6}{*}{0.946} & \multirow{6}{*}{0.745} \\
\hline & ITU2 & 0.857 & & \\
\hline & ITU3 & 0.862 & & \\
\hline & ITU4 & 0.867 & & \\
\hline & ITU5 & 0.846 & & \\
\hline & ITU6 & 0.864 & & \\
\hline
\end{tabular}

TABLE V

DISCRIMINANT VALIDITY BASED ON THE FORNELL-LARKER CRITERION

\begin{tabular}{|c|c|c|c|c|}
\hline & PU & PEOU & PT & ITU \\
\hline PU & $\mathbf{0 . 8 8 8}$ & & & \\
\hline PEOU & 0.589 & $\mathbf{0 . 8 5 9}$ & & \\
\hline PT & 0.285 & 0.362 & $\mathbf{0 . 8 8 3}$ & \\
\hline ITU & 0.422 & 0.372 & 0.385 & $\mathbf{0 . 8 6 3}$ \\
\hline
\end{tabular}

TABLE VI

HYPOTHESIS TESTING

\begin{tabular}{|c|c|c|c|c|c|}
\hline H & Relationship & Beta & $\begin{array}{c}\text { T } \\
\text { value }\end{array}$ & $\begin{array}{c}\text { P- } \\
\text { value }\end{array}$ & Supported \\
\hline H1 & PEOU -> ITU & 0.109 & 1.575 & 0.115 & No \\
\hline H2 & PEOU -> PT & 0.298 & 4.293 & 0.000 & Yes \\
\hline H3 & PEOU -> PU & 0.589 & 14.688 & 0.000 & Yes \\
\hline H4 & PU -> PT & 0.110 & 1.438 & 0.150 & No \\
\hline H5 & PU -> ITU & 0.283 & 4.155 & 0.000 & Yes \\
\hline H6 & PT -> ITU & 0.264 & 4.114 & 0.000 & Yes \\
\hline
\end{tabular}

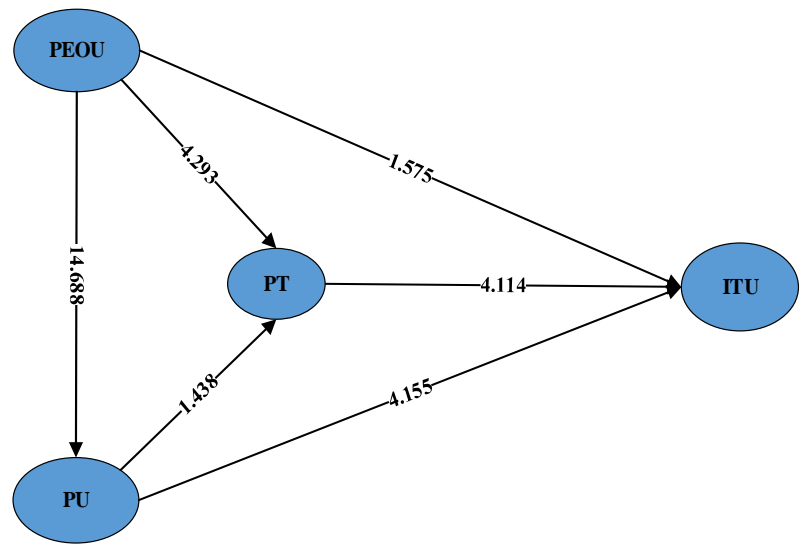

Fig.3 Structural model

\section{CONCLUSIONS}

The present study aimed to examine the effect of PEOU, PU and PT on the acceptance and use of EC services among SMEs managers in Palestine. The relationships among the examined constructs or factors hypothesized based on the TAM and previous related research. The empirical results showed that the extended TAM proposed in this study could explain these relationships. It was valuable in providing empirical evidence underlying the role of PU and PEOU in predicting PT and ITU among managers of EC services. The model also provided these hypothesized which all supported except for H1: (PEOU $\rightarrow$ ITU) and H4: $(\mathrm{PU} \rightarrow \mathrm{PT})$. These results indicate that the extended TAM through the SEM analysis satisfactory. Therefore, the results can benefit by other studies on other information system areas, and particularly, it suits those studies investigating the acceptance of cloud computing and online banking services among individual users. By applying this extended TAM in future research, the validity and reliability of the model will increase besides its contribution to our understanding and knowledge of the research domain. The results of the study meaningfully imply that it is necessary for SMEs as represented by their managers to make effort into enhancing EC services, thus turning them into a user-friendly system. They should also establish and foster PT between these SMEs, specifically EC services and their users or consumers. In order to achieve this, managers of SMEs should intensify their effort into raising the public awareness of the usefulness of EC services among people.

\section{ACKNOWLEDGMENT}

The authors express their thankfulness to Faculty of Information Science and Technology, Universiti Kebangsaan Malaysia for the fund provided under the Fundamental Research Grant Scheme FRGS/2/2014/ICT01/UKM/02/1 to carry out this research.

\section{REFERENCES}

[1] B. Kolarić, R. Petrović, and S. Radojčić, "Application of e-business in modern operation of public companies in Serbia," International Journal of Business Administration, vol. 2, pp. 32-44, 2011. 
[2] F. Herzallah and M. Mukhtar, "Organization Information Ecology and E-Commerce Adoption: Effect on Organizational SMEs Performance," Journal of Computer Science, vol. 11, pp. 540-551, 2015.

[3] A. R. Hamdan, J. H. Yahaya, A. Deraman, and Y. Y. Jusoh, "The success factors and barriers of information technology implementation in small and medium enterprises: an empirical study in Malaysia," International Journal of Business Information Systems, vol. 21, pp. 477-494, 2016.

[4] L. Pham, L. N. Pham, and D. T. Nguyen, "Determinants of ecommerce adoption in Vietnamese small and medium sized enterprises," International Journal of Entrepreneurship, vol. 15, pp. 45-72, 2011.

[5] M. K. Alrousan and E. Jones, "A conceptual model of factors affecting e-commerce adoption by SME owner/managers in Jordan," International Journal of Business Information Systems, vol. 21, pp. 269-308, 2016

[6] A. I. Al-Alawi and F. M. Al-Ali, "Factors affecting e-commerce adoption in SMEs in the GCC: an empirical study of Kuwait," Research Journal of Information Technology, vol. 7, pp. 1-21, 2015.

[7] R. Rahayu and J. Day, "Determinant Factors of E-commerce Adoption by SMEs in Developing Country: Evidence from Indonesia," presented at the Procedia-Social and Behavioral Sciences, 2015.

[8] F. Herzallah and M. Mukhtar, "The Impact of Internal Organization Factors on the Adoption of E-commerce and its Effect on Organizational Performance among Palestinian Small and Medium Enterprise," presented at the International Conference on ECommerce, Sarawak-Malysia, 2015.

[9] R. Fung and M. Lee, "EC-trust (trust in electronic commerce): exploring the antecedent factors," in Americas Conference on Information Systems (AMCIS), 1999, p. 179.

[10] F. Iddris, "Adoption of E-Commerce solutions in small and mediumsized enterprises in Ghana," European Journal of Business and Management, vol. 4, pp. 48-57, 2012.

[11] I. Sila, "Factors affecting the adoption of B2B e-commerce technologies," Electronic commerce research, vol. 13, pp. 199-236, 2013.

[12] J. Mutua, Oteyo, I. N. and A. W. Njeru, "The Strategic Value of ecommerce adoption among Small and Mediam Enterprises in Nairobi, Kenya," in Proceedings of the 2013 Mechanical Engineering Annual Conference on Sustainable Research and Innovation, 2013, p. 133.

[13] P. M. Swatman, "Electronic commerce: origins and future directions," in Proceedings of 1st Australian DAMA (Data Administration Management Association) 1996, p. 1.

[14] G. Schneider, Electronic Commerce, 11th ed. California State University, 2015.

[15] E. Turban, D. king, J. McKay, P. Marshall, J. Lee, and D. Viehland, Electronic Commerce: A managerial Perspective, 5th ed. New Jersey, USA: Prentice Hall, 2008.

[16] D. Fink and G. Disterer, "International case studies: To what extent is ICT infused into the operations of SMEs?," Journal of Enterprise Information Management, vol. 19, pp. 608-624, 2006.

[17] R. Kalakota and A. B. Whinston, Frontiers of electronic commerce: Addison- Wesley, 1996.

[18] K. C. Laudon and C. G. Traver, E-commerce-Business, technology, society, 4th ed.: Boston, Pearson Addison-Wesley, 2009.

[19] F. D. Davis, "Perceived usefulness, perceived ease of use, and user acceptance of information technology," MIS quarterly, vol. 13, pp. 319-340, 1989.

[20] M. Fishbein and I. Ajzen, Belief, attitude, intention and behavior: An introduction to theory and research, MA ed.: Addison-Wesley, Reading, 1975.

[21] P. Luarn and H.-H. Lin, "Toward an understanding of the behavioral intention to use mobile banking," Computers in Human Behavior, vol. 21, pp. 873-891, 2005.

[22] S. Koch, A. Toker, and P. Brulez, "Extending the technology acceptance model with perceived community characteristics," Information Research, vol. 16, pp. 1-28, 2011.

[23] M. Luthfihadi and W. Dhewanto, "Technology Acceptance of Ecommerce in Indonesia," International Journal of Engineering Innovation and Management, vol. 3, pp. 9-18, 2013.

[24] Y. Lee, K. A. Kozar, and K. R. Larsen, "The technology acceptance model: Past, present, and future," Communications of the Association for information systems, vol. 12, pp. 752-780, 2003.
[25] D. Gefen, E. Karahanna, and D. W. Straub, "Trust and TAM in online shopping: an integrated model," MIS quarterly, vol. 27, pp. 51-90, 2003.

[26] A. R. Montazemi and H. Qahri-Saremi, "Factors affecting adoption of online banking: A meta-analytic structural equation modeling study," Information \& Management, vol. 52, pp. 210-226, 2015.

[27] D.-Y. Cho, H. J. Kwon, and H.-Y. Lee, "Analysis of trust in internet and mobile commerce adoption," in Proceedings of the 40th Hawai international conference on system sciences. Hawaii: IEEE., 2007, p. 50.

[28] N. F. Awad and A. Ragowsky, "Establishing trust in electronic commerce through online word of mouth: An examination across genders," Journal of Management Information Systems, vol. 24, pp. 101-121, 2008.

[29] D. M. Wanyoike, E. Mukulu, and A. G. Waititu, "ICT attributes as determinants of e-commerce adoption by formal small enterprises in urban Kenya," International Journal of Business and Social Science, vol. 3, pp. 65-74, 2012.

[30] C. Aydemir, "A Survey Aimed at E-Commerce Applications in Firms Operating in Diyarbakir Organised Industrial Zone," International Journal of Business and Social Science, vol. 4, pp. 43-59, 2013.

[31] S. Ba and P. A. Pavlou, "Evidence of the effect of trust building technology in electronic markets: Price premiums and buyer behavior," MIS quarterly, vol. 26, pp. 243-268, 2002

[32] M. A. Al-Sharafi, A. A. Ruzaini, E. Abu-Shanab, and N. Elayah, "The Effect Of Security And Privacy Perceptions On Customers' Trust To Accept Internet Banking Services: An Extension Of TAM," Journal of Engineering and Applied Sciences, vol. 11, pp. 545-552, 2016.

[33] S. Harridge-March, S. Grabner-Kräuter, and R. Faullant, "Consumer acceptance of internet banking: the influence of internet trust," International Journal of bank marketing, vol. 26, pp. 483-504, 2008.

[34] R. F. Malaquias and Y. Hwang, "An empirical study on trust in mobile banking: A developing country perspective," Computers in Human Behavior, vol. 54, pp. 453-461, 2016.

[35] N. Yousefi and A. Nasiripour, "A proposed model of e-trust for electronic banking," Management Science Letters, vol. 5, pp. 10291040, 2015.

[36] S. Mazidah and H. Burairah, "Profile of ICT innovativeness in Malaysian SMEs from services sector based on core ICT indicators," The Journal of Technology Management and Technopreneurship (JTMT), vol. 2, pp. 51-70, 2014.

[37] M. G. Salimon, R. Z. Yusoff, and S. S. M. Mokhtar, "The influence of e-satisfaction, e-trust and hedonic motivation on the adoption of ebanking and its determinants in Nigeria: A pilot study," Mediterranean Journal of Social Sciences, vol. 7, pp. 54-63, 2016.

[38] D. Gefen and D. W. Straub, "The relative importance of perceived ease of use in IS adoption: A study of e-commerce adoption," Journal of the association for Information Systems, vol. 1, pp. 1-28, 2000

[39] A. Chaudhry, A. Parveiz, and Y. Javed, "Determinants of Users Trust for Branchless Banking in Pakistan," The Journal of Internet Banking and Commerce, vol. 21, pp. 1-15, 2016.

[40] P. A. Pavlou, "Consumer acceptance of electronic commerce: Integrating trust and risk with the technology acceptance model," International journal of electronic commerce, vol. 7, pp. 101-134, 2003.

[41] H. L. Ching and P. Ellis, "Marketing in cyberspace: what factors drive e-commerce adoption?," Journal of Marketing Management, vol. 20, pp. 409-429, 2004.

[42] M. Ghobakhloo, D. Arias-Aranda, and J. Benitez-Amado, "Adoption of e-commerce applications in SMEs," Industrial Management \& Data Systems, vol. 111, pp. 1238-1269, 2011.

[43] B. M. Byrne, Structural equation modeling with LISREL, PRELIS, and SIMPLIS: Basic concepts, applications, and programming: Psychology Press, 2013.

[44] J. C. a. B. Nunnally, I.H. , "Psychometric Theory," ed: New York: McGraw-Hill, 1994

[45] D. P. Andrew, P. M. Pedersen, and C. D. McEvoy, Research methods and design in sport management: Human Kinetics, 2011.

[46] J. F. Hair Jr, G. T. M. Hult, C. Ringle, and M. Sarstedt, A primer on partial least squares structural equation modeling (PLS-SEM): Sage Publications, 2016.

[47] U. Sekaran, "Research methods for business: a skill building approach," Journal of Education for Business, vol. 68, pp. 316-317, 2003. 
[48] J. F. Hair, C. M. Ringle, and M. Sarstedt, "PLS-SEM: Indeed a silver bullet," Journal of Marketing theory and Practice, vol. 19, pp. 139$152,2011$.

[49] J. Henseler, C. M. Ringle, and R. R. Sinkovics, "The use of partial least squares path modeling in international marketing," Advances in International Marketing (AIM), vol. 20, pp. 277-320, 2009.

[50] M. L. Mitchell and M. J. Jolley, Research design explained, 8th ed. Belmont-USA: Jon-David Hague, 2013. 